\title{
The Development of Edmodo-Based E-learning in Mathematics for Class $V$ at Dr. Wahidin Sudirohusodo Primary School
}

\author{
Eddy Harianto, Efendi Napitupulu, Baharuddin
}

Educational Technology Postgraduate Program, Medan State University, Medan, Indonesia

Received: 12 Nov 2020; Received in revised form: 27 Nov 2020; Accepted: 06 Dec 2020; Available online: 12 Dec 2020

(C)2020 The Author(s). Published by Infogain Publication. This is an open access article under the CC BY license

(https://creativecommons.org/licenses/by/4.0/).

\begin{abstract}
This study aims to produce an Edmodo-based e-learning development product in mathematics class $V$ at Dr. Wahidin Sudirohusodo Primary School and to know the feasibility and effectiveness of the developed Edmodo-based elearning media. This study uses a Research and Development $(R \& D)$ approach with ADDIE model where each stage is interconnected and in stages in producing development products. The research subjects in this study are the design, media, learning material experts, the teacher, and the students. The hypothesis proposed of this study is that the development media products on Edmodo-based e-learning are feasible and effective for use in the learning process of mathematics. The data is collected through questionnaire by research subject assessment instrument and posttest from learning outcome instrument. The feasibility of the media is obtained through the validation and testing by research subjects where the average percentage of the results of the assessment of design, media, and learning material experts is $89.3 \%$, while the average percentage of the results of teacher and student assessments in the trial of individual and groups of students is $90.5 \%$ who fall into the "Very Appropriate" category. The product effectiveness test from the learning outcome test data on the research hypothesis test through one-party test obtained $t_{\text {count }}>t_{\text {table }}(2.3798>$ 1.66980), which means that students' mathematics learning outcomes with Edmodo-based e-learning were higher than students who studied conventional truth-tested. Thus development media products on Edmodo-based e-learning are feasible and effective for use in the learning process and can improve student learning outcomes compared to conventional learning.
\end{abstract}

Keywords-E-learning, Edmodo, Mathematics, Media.

\section{INTRODUCTION}

In this modern era, which is often referred to as the era of the industrial revolution 4.0, of course, technology is increasingly needed to assist human activities in their daily lives. Even the world of education has not escaped this touch of technology. In the world of education today, the use of technology in the learning process is one of the important things in supporting the quality of learning itself.

The rapid development and advancement of technology encourages changes in world globalization. (Murray, 2012) explained every change is called learning because learning arises from the need to survive in social, economic and cultural terms which are also triggered by the environment. Even the presence of this globalization cannot be avoided by the world of education. The development of globalization has triggered a tendency to shift in the world of education from conventional face-to-face meetings to a more open and flexible education (Budiman, 2017). This makes education today must always adapt to the times in facing the fast flow of information and knowledge through information and communication technology.

Conventional face-to-face learning still occurs at Dr. Wahidin Sudirohusodo Primary School. Based on the results of observations and interviews with several teachers and students, it was found that face-to-face conventional learning like that tends to be boring and does not provide motivation in the learning process that occurs. Even though some teachers have used learning media in schools such as physical props and textbooks, the learning that occurs is still mostly teacher-centered and does not involve the active participation of students. 
Student-centered learning is learning that involves students both individually and in groups in solving a problem and being active learners in seeking and finding knowledge, not just accepting it (Harmon \& Hirumi, 1996). The learning process should use learner-centered principles that can develop creativity, a fun and challenging atmosphere, and also provide a diverse learning experience through the application of various learning strategies and methods (Warso, 2017). This shows that learning currently makes students the center in the learning process that must be active while the teacher functions as a facilitator in the learning.

Mathematics is one of the subjects that is avoided by many children even though learning mathematics is very important and useful because the knowledge in mathematics has been widely used in various other fields of science. (Bangun, 2016) stated "in mastering and creating future technology requires a strong mastery of mathematics". So we need a mathematics learning that emphasizes innovative learning media to improve student learning outcomes (Nugroho \& Purwati, 2015).

Through advances in technology and information today, student-centered learning can be done with e-learning. Elearning is a type of teaching and learning where teaching materials are delivered to students using the internet, intranet or other computer network media (Hartley, 2001). This e-learning offers flexibility and flexibility where the collaborative learning that is presented can be accessed widely, anytime, and anywhere (Fuady, 2016).

There are many types of online learning (e-learning) that can be used today such as the Learning Management System (LMS). Edmodo is one type of LMS that is easy to use with an interactive and practical display. Students also get new learning experiences through Edmodo, can be more expressive, the learning atmosphere (chat) is very relaxed, and learning materials can be accessed anywhere and anytime if students forget the material he has learned (Pratama \& Ismiyati, 2019).

This development research is focused on developing elearning using Edmodo as a learning platform that is conducted online to provide meaningful and studentcentered learning experiences. The use of Edmodo is expected to help teachers and students especially in mathematics to get better learning outcomes and take advantage of more technology in the learning process to prepare future generations of Indonesia who are ready to compete in the era of the industrial revolution 4.0.

\section{THEORETICAL FRAMEWORK}

\subsection{Learning}

Learning occurs due to the interaction between stimulus and response (Slavin, 2014). A person is considered to have learned if he can show changes / responses to a stimulus given to him. The stimulus is the input while the resulting response is the output. (Fiorella \& Mayer, 2015) stated that "learning is a generative activity when learners actively generate their own learning outcomes by interpreting what is presented to them rather than by simply receiving it as presented". Learning is a change in one's behavior or abilities, which can be sustained, and not just considered a growth process (Gagne, 1970).

Thus, learning can be interpreted as an activity to acquire knowledge through a stimulus provided by the teacher where students actively respond to the information provided so that behavior changes are formed based on experiences that occur in achieving the desired learning outcomes

\subsection{Learning Outcomes}

Learning outcomes are abilities that students have after experiencing the learning process. Learning outcomes can indicate the extent to which students understand the material or information provided in the learning process. Learning outcomes are results in the form of scores or numbers achieved by students after being given a learning outcome test within a certain time (Dimyati \& Mudjiono, 2006). Bloom (Bloom, Engelhart, Furst, Hill, \& Krathwohl, 1956) divides learning outcomes into three domains, namely cognitive domain, affective domain, and psychomotor domain. Learning outcomes can reveal holistically from the description of student achievement after going through learning (Sutrisno \& Siswanto, 2016).

Therefore, learning outcomes can be interpreted as a learning experience that can be measured to describe the achievement of students after going through the learning process and includes aspects of cognitive (knowledge), affective (attitudes), and psychomotor (skills).

\subsection{Mathematics}

Mathematics as a pattern of thinking, organizational patterns, and logical proof (Johnson \& Rising, 1972). Courant (Courant \& Robbins, 1996) in his book What is Mathematics ?: An Elementary Approach to Ideas and Methods which was revised by Stewart wrote "Mathematics as an expression of the human mind reflects the active will, the contemplative reason, and the desire for aesthetic perfection". It is further explained that mathematics departs from logic and intuition, analysis and construction, generalization and individualization. 
James and James (James \& James, 1976) say that mathematics is the science of logic regarding the form, arrangement, quantity, concepts that are related to one another in large numbers and divided into three fields, namely algebra, analysis, and geometry.

From some of the definitions above, it can be concluded that mathematics is the study of quantity, structure, space, change and other concepts that are related to one another and departs from deep logical thinking and then through reasoning produces generalized expressions of thought.

Mathematics learning in the 2013 curriculum uses a scientific approach which includes observing, asking, gathering information / trying, associating / processing information / reasoning, and communicating or better known as the $5 \mathrm{M}$ steps in the scientific approach (Rusman, 2015).

\subsection{E-learning}

E-learning is a type of teaching and learning that allows teaching materials to be delivered to students using the internet, intranet or other computer network media (Hartley, 2001). E-learning is the use of internet technology to deliver a series of solutions that can increase knowledge and skills (Rosenberg, 2001). It can be concluded that e-learning is distance learning that utilizes one or more electronic technologies to support the learning process via the internet network.

The e-learning function for learning activities in the classroom (classroom instruction) is divided into three, namely (1) supplement; (2) complement; and (3) substitution. E-learning is said to be a supplement if students have the flexibility to choose whether to take advantage of the learning content contained in e-learning or not. e-learning as a complement aims to complement the learning material provided by the teacher. In this case, students access learning content in e-learning to increase their understanding of learning material. E-learning is said to function as a substitute if e-learning is used to substitute learning activities, for example by using learning activity models.

E-learning provides an interesting and meaningful learning experience for students because of its ability to integrate directly so that understanding of learning material will be more meaningful, easy to understand, easy to remember and easy to re-express.

\subsection{Edmodo}

Edmodo is a social networking learning platform for teachers, students and parents developed in late 2008 by Nic Borg and Jeff O'Hara. (Pitoy, 2012) says Edmodo is a social media platform for teachers and students to share ideas, files, agendas, activities, and assignments. Edmodo aims to help teachers use social media in the learning process because Edmodo's appearance and features are similar to Facebook, but not as free as those on Facebook. This Edmodo feature is designed specifically for the world of education so that there will be interactions between teachers, students, and even parents.

Some of Edmodo functions include: (1) to facilitate communication between students and students or with teachers or teachers and students; (2) as a means of communication learning and discussion; and (3) as a place for exams / quizzes, and so on. Edmodo has features that are devoted to supporting the learning process. These features are classified based on users, namely teachers and students.

\section{RESEARCH METHOD}

\subsection{Research Design}

This research uses a research and development approach (R\&D) with the ADDIE development model which consists of five main stages, namely the analysis stage, the design stage, the development stage, the implementation stage, and the evaluation stage.

The analysis stage includes analysis of needs, learning and characteristics of students' initial abilities, determining basic competencies and indicators of learning achievement.

The design stage includes designing the e-learning display and learning strategies as well as the collection of materials needed for product development according to predetermined basic competencies in the form of subject matter and other supporting aspects such as text, images, animation, audio, and video.

The development stage is the assembling of the media / combining all materials such as subject matter, pictures, animation, text, and learning videos.

The implementation stage is the application of Edmodobased e-learning which has been developed to determine the responses of teachers and students to e-learning that was developed in terms of appearance and feasibility.

At the evaluation stage, an assessment is carried out from the data that has been collected during the implementation stage. The evaluation obtained is in the form of formative and summative evaluations to determine the level of validation and its effectiveness on learning outcomes and learning quality. Formative evaluation is carried out to measure or assess learning products which include expert validation evaluations, individual, small group, and field trials. While summative evaluation is at the conclusion stage of a learning product. Summative 
evaluation is carried out to determine whether the product developed is effective or not in the learning process by conducting an effectiveness test.

\subsection{Research Subject}

Learning development products require feedback in the context of formative evaluation. This feedback can be obtained from research subjects consisting of instructional design experts, material experts, media experts, teachers, and students of class V (five) at Dr. Wahidin Sudirohusodo Primary School.

\subsection{Research Instrument}

The data collection instrument in this development research is in the form of an assessment tool to assess the products being developed. The main instruments used to collect data in this study are as follows (1) questionnaire sheet; (2) interview; and (3) learning outcome test instrument.

The questionnaires used in this study were: (1) questionnaire sheet for material experts; (2) a questionnaire sheet for learning design experts; (3) questionnaire sheet for instructional media experts; and (4) questionnaire sheets for teachers and students.

Interview sheets are used as a means of collecting additional data from material experts, design experts, media experts, teachers, and students in the form of suggestions, criticisms, and input obtained when conducting trials.

Learning outcome tests are used to see the effectiveness of the use of Edmodo-based e-learning in learning compared to conventional learning. The form of learning outcomes test used is multiple choice with four choices (a, $\mathrm{b}, \mathrm{c}$, and d) where each correct answer is 1 and the wrong answer is 0 (zero).

The learning outcome test instrument that had been compiled was tried out on grade VI students to determine the quality of the instrument in the form of validity, reliability, level of difficulty, distinguishing power. From the results of the learning outcomes test instrument trial, 20 items were selected to be used in the product effectiveness test

\subsection{Data Analysis}

Data analysis in this development research uses quantitative descriptive analysis, where all data that has been collected from the questionnaire are analyzed using descriptive statistical techniques which are quantitatively grouped by category to sharpen the assessment in drawing conclusions. The product development criteria will be converted into values using a Likert scale with the following formulas and criteria:

$$
\begin{gathered}
x=\frac{\text { the number of scores obtained }}{\text { total ideal score of all items }} \times 100 \% \\
\text { Table 1: Assessment Criteria }
\end{gathered}
$$

\begin{tabular}{ccc}
\hline Grade & Criteria & $\begin{array}{c}\text { Percentage } \\
(\boldsymbol{\%})\end{array}$ \\
\hline A & Very Appropriate & $81-100$ \\
B & Appropriate & $61-80$ \\
C & Pretty Good & $41-60$ \\
D & Less Appropriate & $21-40$ \\
E & Very Inappropriate & $0-20$ \\
\hline
\end{tabular}

Source: (Sugiyono, 2015)

For quantitative data obtained from student learning outcomes in this study using a Posttest-Only Control Group Design experimental design, namely by comparing the posttest scores of students who used Edmodo-based e-learning developed with students who did not use Edmodo. The data analysis technique used is descriptive and inferential techniques.

Descriptive techniques are statistics used to analyze data by describing the data that has been collected without intending to draw general or generalized conclusions. Data presentation in the form of tables, diagrams, histograms, calculation of the mean, median, and standard deviation without significance testing.

Inferential techniques in this study using one-party t-test to test the hypothesis proposed in the study as follows:

$$
t=\frac{\overline{x_{1}}-\overline{x_{2}}}{s \sqrt{\frac{1}{n_{1}}+\frac{1}{n_{2}}}}
$$

Where, $\mathrm{t}=$ value of $\mathrm{t}$ count; $\bar{x}=$ sample mean; $\mathrm{s}=$ sample standard deviation; and $\mathrm{n}=$ number of samples.

\section{RESULTS AND DISCUSSION}

The development of Edmodo-based e-learning media in mathematics learning with the topic of multiplying fractions is carried out in stages. The development process is carried out in accordance with the stages of the development process which includes the stages of analysis, design, development, implementation (testing), and evaluation.

The analysis stage which included needs analysis was carried out by distributing questionnaires as well as conducting interviews based on a list of questions that had been compiled in a questionnaire to 3 teachers and 28 students at Dr. Wahidin Sudirohusodo Primary School by first outlining the definition of research development 
carried out so that respondents have an idea of the questions to be asked.

The results of this analysis activity found that all students still used textbooks as the main source of learning and $42 \%$ of students were able to find other learning sources besides text books such as videos or other electronic information. The learning methods used by teachers so far are still mostly lecture methods with occasional use of teaching aids or learning media in class. As much as $57 \%$ of students stated that mathematics was difficult to learn, especially regarding fractions because students were not explained about concepts related to everyday life and had limited time to ask questions when they encountered difficulties in learning, while $79 \%$ of students had difficulty understanding the material through the teaching materials and methods applied.

Teachers and students already has a laptop and a cell phone that supports internet networks and most students ( $86 \%$ of students) stated that they are used to using the internet and electronic devices in their daily life. Students have never known and learned to use Edmodo while teachers have known Edmodo but have never applied it in the learning process. In addition, teachers (100\%) and students (93\%) agree that learning is developed using Edmodo.

Based on the results of this needs analysis, it can be concluded that the development of Edmodo-based elearning media is really needed by teachers and students in the mathematics learning process to facilitate studentcentered learning that is flexible, fun, and challenging in accordance with current technological developments.

Furthermore, an instructional analysis and the characteristics of the initial abilities was carried out according to the curriculum and syllabus currently being used in Dr. Wahidin Sudirohusodo Primary School which contains learning material to be used as a guide in determining basic competencies, the order of learning materials and also indicators of achievement of learning outcomes. The characteristics of the initial ability of grade $\mathrm{V}$ (five) students are students aged between 9-11 years and are already familiar with the use of technology and the internet where their initial abilities are familiar with fractions and master the addition and subtraction of fractions and decimals.

The result of the analysis of mathematics learning in the 2013 curriculum that is applied in schools is the determination of the basic competence of mathematics for class V (five) Odd Semester on the core competencies of knowledge, namely explaining and determining the multiplication and division of fractions and decimals. The sub-material used is the multiplication of fractions with the learning sequence which is divided into 4 (four) meetings in the Learning Implementation Plan.

At the design stage, the concept design and initial appearance of the mathematics learning space in Edmodo are carried out through storyboarding. Then determine the learning strategy used in the learning process using Edmodo, namely STAD (Student Team Achievement Division). The selection of learning strategies used is adjusted to the characteristics of students and Edmodo's carrying capacity in implementing the mathematics learning process. Subject matter materials and supporting aspects are collected through textbooks that are being used as well as other sources in the form of text or images used in making learning media.

At the development stage, the media is assembled and made based on the previously made designs. The making of learning media in the form of learning videos which also includes learning instructions, material summaries, and assignments or exercises are carried out separately and gradually, then combined into Edmodo in the form of a learning folder in a previously made classroom. Furthermore, the evaluation questions were made in Edmodo application using the quiz feature based on the learning outcome test instrument that has been tested for validity and reliability.

The stages of testing or implementation of learning media that have been developed are carried out according to the stages of the trial implementation which includes testing and validation of media experts, material experts, and learning design experts, teachers, and students where the results of trials and validation on each research subject are used as the basis implementation of revision of learning media development so that the media developed in the end can be said to be suitable for use.

The evaluation stage is also the stage of media revision after getting the results of the trials carried out according to the suggestions and comments given by the research subjects. After being revised to fit the eligibility category of Edmodo-based e-learning media, then a trial of the implementation of learning in the experimental class was carried out on the fifth grade students at Dr. Wahidin Sudirohusodo Primary School to find out the effectiveness of the learning media that has been developed.

The average percentage of the results of the assessment of instructional design experts, instructional media experts, and learning material experts is as follows: 
Table 2: Average Percentage of Expert Validation Results

\begin{tabular}{cccc}
\hline No & Validation & Percentage & Criteria \\
\hline 1 & $\begin{array}{c}\text { Design } \\
\text { Experts }\end{array}$ & $85,3 \%$ & $\begin{array}{c}\text { Very } \\
\text { Appropriate }\end{array}$ \\
2 & Media & $93,3 \%$ & Very \\
& Experts & & Appropriate \\
3 & Material & $89,3 \%$ & Very \\
& Experts & & Appropriate \\
\hline & Average & $89,3 \%$ & Very \\
& & & Appropriate \\
\hline
\end{tabular}

From the average percentage of the results of the three experts' assessment, $89.3 \%$ was included in the "Very Appropriate" category, which means that the development of Edmodo-based e-learning media in mathematics class $\mathrm{V}$ (Five) at Dr. Wahidin Sudirohusodo Primary School fulfills the need and is suitable for use by teachers and students.

The average percentage of the assessment aspects of the results of teacher and student assessments in individual and group student trials can be seen in the following table:

Table 3: Average Percentage of Teacher and Student Assessment Results

\begin{tabular}{cccc}
\hline No & Evaluator & Percentage & Criteria \\
\hline 1 & Teachers & $91,0 \%$ & $\begin{array}{c}\text { Very } \\
\text { Appropriate }\end{array}$ \\
& & & Very \\
2 & Students & $91,5 \%$ & Appropriate \\
& $\begin{array}{c}\text { (Individual } \\
\text { Trial) }\end{array}$ & & Very \\
& Students & $89,0 \%$ & Appropriate \\
& (Group & & Very \\
& Trial) & & Appropriate \\
\hline
\end{tabular}

From the average percentage of teacher and student assessments of $90.5 \%$ which fall into the "Very Appropriate" category, which means the development of Edmodo-based e-learning media in mathematics in class $\mathrm{V}$ (Five) at Dr. Wahidin Sudirohusodo Primary School deserves to be used and has benefits in the learning process between teachers and students.

Based on the results of the study after learning process using lectures methods, obtained the following data where the highest mark is 100 and the lowest mark is 20 with the mean of 69.53 .
Table 4: Frequency Distribution of Learning Outcomes of Control Class

\begin{tabular}{cccc}
\hline No & Interval & $\begin{array}{c}\text { Frequenc } \\
\mathrm{y}\end{array}$ & $\begin{array}{c}\text { Relative } \\
\text { frequency }\end{array}$ \\
\hline 1 & $20-33$ & 3 & 9.375 \\
2 & $34-47$ & 3 & 9.375 \\
3 & $48-61$ & 5 & 15.625 \\
4 & $62-74$ & 3 & 9.375 \\
5 & $75-87$ & 8 & 25 \\
6 & $88-100$ & 10 & 31.25 \\
\hline & Total & 32 & $100 \%$ \\
\hline
\end{tabular}

The frequency distribution of learning outcomes shows that most of the students who got posttest result between mark of 75 and 100 is 18 pupils, while there are 14 students who got the posttest result between mark of 20 and 74 .

The results of the study after learning process using Edmodo-based e-learning media, obtained the following data where the highest mark is 100 and the lowest mark is 55 with the mean of 81.25 .

Table 5: Frequency Distribution of Learning Outcomes of Experimental Class

\begin{tabular}{cccc}
\hline No & Interval & $\begin{array}{c}\text { Frequenc } \\
\mathrm{y}\end{array}$ & $\begin{array}{c}\text { Relative } \\
\text { frequency }\end{array}$ \\
\hline 1 & $55-62$ & 4 & 12.5 \\
2 & $63-70$ & 6 & 18.75 \\
3 & $71-78$ & 1 & 3.125 \\
4 & $79-86$ & 8 & 25 \\
5 & $87-94$ & 5 & 15.625 \\
6 & $95-100$ & 8 & 25 \\
\hline & Total & 32 & $100 \%$ \\
\hline
\end{tabular}

The frequency distribution of learning outcomes of experimental class shows that there are 22 students who got mark between 71 and 100. Then there are 10 students got mark between 55 and 70 .

Based on the learning outcomes research data on the experimental group that show $84.375 \%$ of the students have passed the minimum learning completeness of 70 which is categorized as high and $15.625 \%$ got the mark below 70 which is categorized as average, it means that the results of learning on subjects who were given treatment in the experimental class is likely to be high. 
The result of the one party t-test proves that students' mathematics learning outcomes with Edmodo-based elearning are higher than students learning conventionally. So it can be concluded that Edmodo-based e-learning media that has been developed in mathematics on the topic of multiplying fractions at Dr. Wahidin Sudirohusodo Primary School is more effective in improving learning outcomes.

\section{CONCLUSION}

Based on the results of the research that have been conducted, it can be drawn the conclusion that production of Edmodo-based e-learning media which begins with collecting information, analyzing student needs and characteristics, formulating learning materials, designing and developing products, validating and revising, until product testing shows that media products that have been developed in Edmodo-based e-learning is suitable for use in fifth grade mathematics at Dr. Wahidin Sudirohusodo Primary School where the average result of expert validation was $89.3 \%$ as well as the average teacher and student assessment of $90.5 \%$ which was included in the "Very Appropriate" category.

Edmodo-based e-learning media products are effective in the learning process and can improve student learning outcomes compared to conventional learning. This can be seen from the results of the learning outcomes where $84.375 \%$ of the students on the experimental class have passed the minimum learning completeness of 70 compared with $59.375 \%$ of the students on the control class. The results of the hypothesis test where $t_{\text {table }}=1.66980$ with a significance level of $5 \%$ while the value of $t_{\text {count }}=2.3798$, then $t_{\text {count }}>t_{\text {table }}=2.3798>1.66980$, which means that students' learning outcomes of mathematics using Edmodobased e-learning has a higher accuracy with an effectiveness of $84.375 \%$ compared to students who learn conventionally with an effectiveness of $59.375 \%$.

\section{REFERENCES}

[1] Bangun, J. D. (2016). Pengembangan Media Pembelajaran Interaktif Matematika Siswa Kelas VII SMP Swasta Nurcahaya Medan. Medan: Universitas Negeri Medan.

[2] Bloom, B., Engelhart, M., Furst, E., Hill, W., \& Krathwohl, D. (1956). Taxonomy of Educational Objectives: Handbook 1, Cognitive Domain. New York: David McKay.

[3] Budiman, H. (2017, May). Peran Teknologi Informasi Dan Komunikasi Dalam Pendidikan. Jurnal Pendidikan Islam, 8, 75-83.

[4] Courant, R., \& Robbins, H. (1996). What is Mathematics? : An Elementary Approach to Ideas and Methods. New York: Oxford University Press.
[5] Dimyati, \& Mudjiono. (2006). Belajar dan Pembelajaran. Jakarta: Rineka Cipta.

[6] Fiorella, L., \& Mayer, R. (2015). Learning as a Generative Activity. Cambridge University Press.

[7] Fuady, M. J. (2016, September). Pengembangan Aplikasi Evaluasi Pembelajaran Online Untuk Pendidikan Jarak Jauh. TEKNO, 26, 148-154.

[8] Gagne, R. (1970). The Conditions of Learning (Second Edition). New York: Holt, Rinehart and Winston, Inc.

[9] Harmon, S., \& Hirumi, A. (1996). A Systematic Approach to the Integration of Interactive Distance Learning into Education and Training. Journal of Education for Business, 71(5), 267. Retrieved from https://www.learntechlib.org/p/80025/

[10] Hartley, D. (2001). Selling E-Learning. Alexandria: ASTD.

[11] James, G., \& James, R. (1976). Mathematics Dictionary. New Jersey: John Wiley \& Sons.

[12] Johnson, D., \& Rising, G. (1972). Guidelines for Teaching Mathematics. Belmont: Wadsworth Pub. Co.

[13] Murray, J. (2012). Cybernetic Principles of Learning. In: Seel N. M. (eds). Boston, MA: Springer. doi:10.1007/978-14419-1428-6

[14] Nugroho, A. A., \& Purwati, H. (2015). Pengembangan Media Pembelajaran Matematika Berbasis Mobile Learning Dengan Pendekatan Scientific. Jurnal Euclid, 2(1), 174-182.

[15] Pitoy, Y. (2012, Oktober 18). Mathematics Excited With Edmodo. Retrieved from http://yanipieterpitoy.wordpress.com

[16] Pratama, R. A., \& Ismiyati, N. (2019). Pembelajaran Matematika Berbasis Edmodo Pada Mata Kuliah Teori Bilangan. Jurnal Program Studi Pendidikan Matematika, 8(2), 298-309. doi:10.24127/ajpm.v8i2.2125

[17] Rosenberg, M. (2001). E-learning: Strategies For Delivering Knowledge In The Digital Age. USA: McGrawHill Companies.

[18] Rusman. (2015). Pembelajaran Tematik Terpadu. Jakarta: Raja Grafindo Persada.

[19] Slavin, R. (2014). Educational Psychology: Theory and Practice (Tenth Edition ed.). Pearson Education Limited.

[20] Sugiyono. (2015). Metode Penelitian Kuantitatif, Kualitatif, $R \& D$. Bandung: Alfabeta.

[21] Sutrisno, V. L., \& Siswanto, B. T. (2016, Februari). FaktorFaktor Yang Mempengaruhi Hasil Belajar Siswa Pada Pembelajaran Praktik Kelistrikan Otomotif SMK Di Kota Yogyakarta. Jurnal Pendidikan Vokasi, 6(1), 111-120. Retrieved from http://journal.uny.ac.id/index.php/jpv

[22] Warso, R. D. (2017). Pengembangan E-learning Menggunakan Schoology Pada Mata Pelajaran Mesin Konversi Energi Di SMK Negeri 2 Tanjung Balai. Medan: Universitas Negeri Medan. 